Cultura e sociedade 


\title{
Os fugitivos e os mastins: em torno dos homens brutos de Cairu
}

\author{
PEDRO MEIRA MONTEIRO
}

\author{
“...o homem, ali, é ainda um intruso impertinente." \\ (Euclides da Cunha. "Terra sem História (Amazônia)”)
}

Para Luiz Dantas

I

NICIO PELO que me parece sempre importante: reconhecer a gênese de um trabalho. Entender de onde vem um trabalho talvez não seja simplesmente reconhecer a fonte de uma inspiração, mas sim entender a nós mesmos diante da fonte; como se todo trabalho fosse no fundo uma reação, de indignação, curiosidade ou simples interesse.

Este ensaio é uma pequena reflexão feita a partir de algumas linhas de investigação com que procurei cercar, em pesquisa anterior, uma obra singular, relativamente desconhecida, do visconde de Cairu.

Cairu, como se sabe, foi uma personagem importante do cenário político e intelectual brasileiro e luso-brasileiro. Mais conhecido no campo da Economia Política - no qual se concentra sua obra -, foi um dos idealizadores da abertura dos portos em 1808. Posteriormente, já no contexto da Independência, foi um dos principais censores da corte. Correndo o risco da caricatura, Cairu terá sido um dos mais importantes conservadores, ou melhor, reacionários, da história política brasileira.

Uma pequena e importante parte de sua obra, entretanto, vem de outro campo: a moral.

Cairu situa-se precisamente naquela zona de sombra em que uma ciência da regulação doméstica (a economia) tenta, dramaticamente, emancipar-se de sua origem moral. Recorrendo seguidamente a Adam Smith, é à Teoria dos sentimentos morais que ele se refere, tanto quanto à Investigação sobve a natureza e as causas da riqueza das nações. Num importante manual intitulado Constituição moral e deveres do cidadão, publicado entre 1824 e 1825 na Imprensa Régia do Rio de Janeiro (obra curiosamente deixada na sombra por muitos dos comentaristas $^{1}$ ), Cairu nos oferece algumas das pedras de toque de um pensamento contra-revolucionário imensamente rico, até mesmo porque prenunciador de uma linhagem de longa duração e muito sucesso na história política e intelectual brasileira. Foi essa obra que, em primeiro lugar, interessou-me. ${ }^{2}$

Há, no entanto, uma gênese deste trabalho mais tópica, em todo caso menos tropical, e talvez mais interessante, ou simplesmente curiosa. Tal origem 
pode levar-nos longe de Cairu, mas talvez valha a pena manter o visconde um pouco a distância, para encontrá-lo rapidamente, e em seguida deixá-lo para trás. Enfim, proponho que nos movimentemos em torno daquilo que Cairu chamaria de homens brutos ou, mais precisamente, semibrutos.

Por longo tempo, eu procurava imaginar qual a melhor forma para referirme ao campo unificado da moral e da política no pensamento do visconde de Cairu - a proposição original -, sem no entanto repetir idéias e textos anteriores. A instância por escrever - instância da escrita - vinha me assombrando e foi - aí a gênese - num Museu de História Natural que a idéia se esclareceu, e, talvez não à toa, ela se esclarece com o impacto causado por algumas imagens.

Como em todo museu, havia ali, no Museu de História Natural de Nova York, uma história da composição do acervo, uma complexa construção de significados e uma lógica que se impõe desde o século XIX. (Será quase pleonástico sugerir que um museu venha do século XIX; a bem da verdade, um museu é o século XIX.)

Em primeiro lugar, o museu é uma criação daquele século, porque não se compreende a idéia fantástica da exposição sem o pressuposto político do espaço público, e do indivíduo que se move por ele. Mas por trás de toda exposição há uma lógica tão mais forte quanto oculta. O segredo de um museu (segredo do século XIX) está na naturalização dessa lógica, que é a naturalização do olhar e da sensibilidade do público. Então - eis o segredo -, o que eu vejo é a história natural, a evolução do homem, ou o seu distanciamento da natureza.

Em segundo lugar, mais uma marca do século XIX é o apagamento quase definitivo da esfera divina nesse espaço de observação: em alguns museus, o que eu vejo pode não ser mais que a procissão laicizada dos símbolos da pátria, ou dos heróis nacionais que o século XIX construiu, montando aquilo que é o velho Panteão clássico, agora como justificativa do Estado Nacional. ${ }^{3}$ Já no campo da "história natural", que nos interessa aqui mais de perto, o museu evidentemente expõe as teorias evolutivas do século XIX, mas o momento talvez mais significativo na exposição seja aquele instante fundamental e fundante em que o homem se investe de sua humanidade, e abandona portanto o âmbito da natureza.

Um dos pavilhões mais impressionantes do Museu de História Natural pode ser, justamente, o dos “povos da África”. Mas o que se vê, afinal, nas vitrines do Museu de História Natural de Nova York?

O que ali se dá, de forma algo assustadora, é a dramatização do processo histórico - o que já é, malgrado a profissão de fé científica na objetividade (característica do século XIX), uma montagem, no sentido propriamente teatral do termo. ${ }^{4} \mathrm{O}$ que eu vejo são homens em movimento, e é notável, sobretudo num país que tem o cinema como sua grande arte, que os manequins do século XX, na sua devida ambiência e na contraluz provida pela montagem, sejam capazes de representar, de fato, cenas, tomadas em movimento, de algo como um encontro. Mas qual encontro? 
Creio que se possa plausivelmente dizer que nas cenas em tela o homem se encontra diante da natureza, ou do domínio da natureza. Essas as forças postas em choque: o Homem e a Natureza. Interessantemente, o que parece definir a humanidade, na cadeia lógica - e natural - da exposição, será o controle da natureza, dos animais e das plantas, garantindo aos quadros, às tomadas, aos closes, a ambiência propriamente neolítica que eles têm, marcando, como fundação histórica e natural da humanidade, o domínio das artes agrícolas e pecuárias.

Ao retirar do gado o sangue, num processo já bastante distante da simples captura do animal, o homem vai fundando a sua sociabilidade.

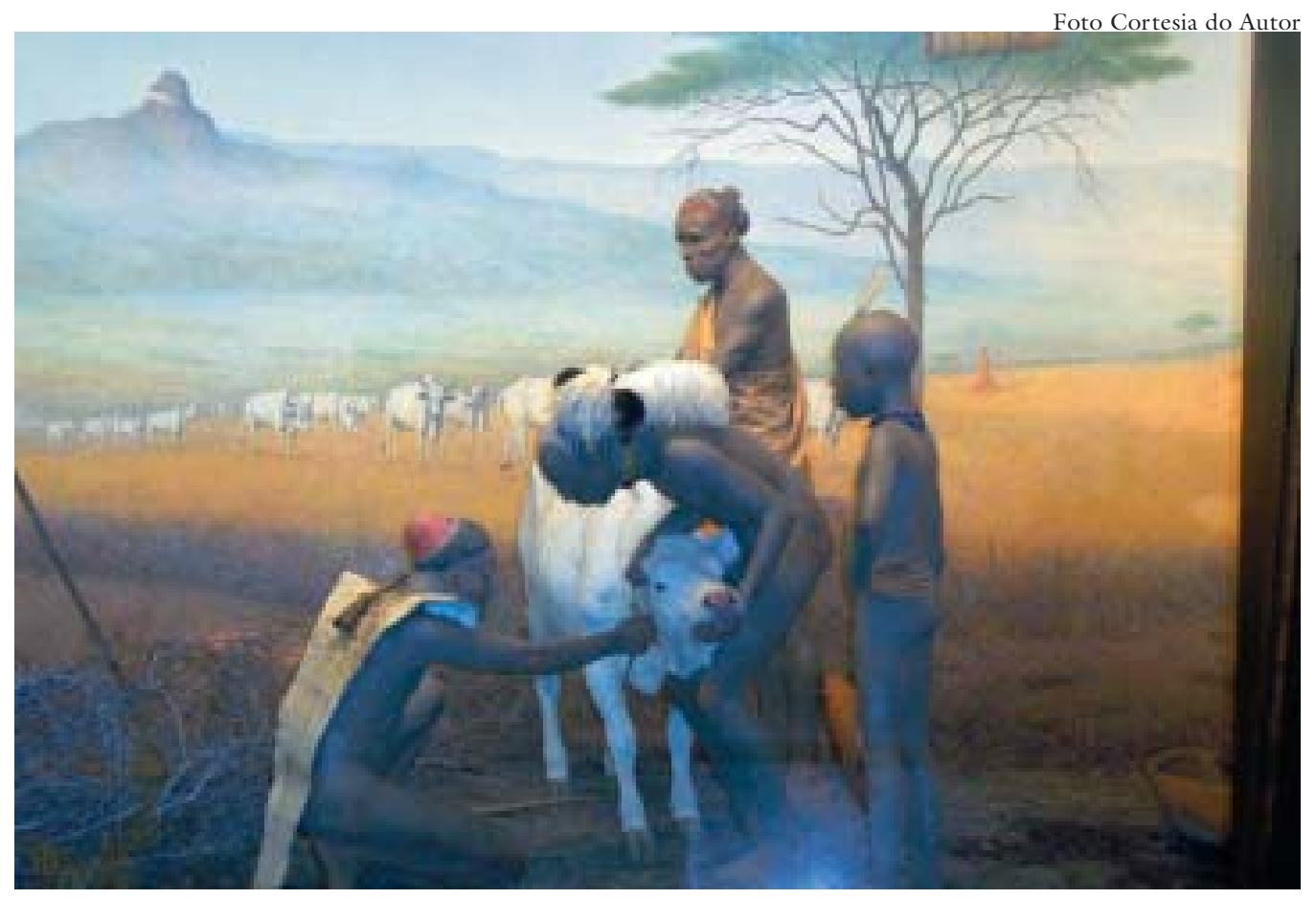

Figura l - Os Pokot, nas "Savanas" africanas, Museu de História Natural de Nova York, Sala dos Povos africanos, foto PMM, 2003.

Há um outro plano, ainda mais interessante: o domínio dessa sorte de fundo selvagem que descansaria em cada um de nós, ou em cada um de nós que se encontra na vitrine, que aí se torna um espelho, num sentido nem tanto pedagógico, como quereria o visconde de Cairu. O que mais fundo impressiona, nas legendas a ilustrar as cenas, é a necessidade de marcar, como num ato simbólico, o momento em que os homens se agrupam e estabelecem a norma social, a qual, como se sabe, é exatamente a proibição, o interdito que marca os limites e que, ao marcar os limites da ação (estabelecendo a punição) e dos homens (estabelecendo os espaços sociais), celebra os marcos da coletividade, isto é, estabelece aquilo que caracteriza e enforma a coletividade, num inequívoco domínio ritual da natureza: 
Entre os Pokot, como com vários povos da savana, a agricultura é economicamente tão importante quanto a pecuária, mas a pecuária está intimamente associada a noções de riqueza e prestígio, e ligada a valores religiosos. Um momento central de cada dia é a retirada indolor de uma pequena quantidade de sangue do pescoço do gado novo, que não sofre, já que nenhum boi é sangrado mais que uma vez a cada um ou dois meses. Assim como os campos são a província das mulheres, o espaço de criação do gado é a província dos homens. Os próprios homens dividem-se em várias faixas etárias, cada qual com um papel apropriado a desempenhar, e distinguida pela maneira de falar e vestir-se. Em ocasiões como essa, pessoas de várias faixas etárias podem cooperar, em outras elas devem manter-se separadas. As mulheres podem ser vistas vindo dos campos irrigados das montanhas masob, enquanto o gado é trazido da planície keiou. O kamass central é também o centro social em que todos os Pokot interagem, e contém os santuários em torno dos quais todos devem reunir-se. ${ }^{5}$

Enfim, o que talvez se possa ou se tente flagrar nas vitrines seja o momento preciso em que inequivocamente (a lógica é sempre forte) o afastamento da natureza significa a delimitação do humano, que é o social, ou seja, nas imagens se revela a expulsão ritual do espaço natural-selvagem, e a aceitação da norma, que é justamente o estabelecimento de uma liturgia profana em torno do social, ou aqui, como faz questão de marcar a legenda nossa contemporânea, uma liturgia ainda religiosa.

Mas é claro, ainda outra vez, que estamos no século XIX, e uma ciência do social - a sociologia - tem seu berço aí, nessa busca de uma outra natureza (a natureza social). Uma ciência capaz de expor a regularidade da ação, e é curioso que, ao menos no caso da imagem em questão, a reunião dos homens se dê sem que o plano propriamente religioso se revele de imediato, como se estivéssemos, porventura, diante de uma liturgia profana - expressão que bem poderia definir o trabalho, tout court.

Parece clara, quando o olhar do século XIX congela a cena, a regularidade garantida pela norma, isto é, a previsibilidade da ação, limitada e informada pelos rituais sociais. Essa é a proposição de uma sociologia nascente, este é o berço clássico da sociologia francesa, que, conquanto amparada na curiosidade etnológica do século XIX, enfrentava o mundo emerso da experiência revolucionária - mundo, se não selvagem, ao menos, numa certa imaginação sociológica original, instintivo. ${ }^{6}$ Aliás, uma viagem pelas vitrines do Museu de História Natural de Nova York pode sugerir não apenas o nascimento da moderna sociologia, mas ainda, como me disse um outro visitante, uma viagem pelo inconsciente freudiano: o encontro e a miragem do primitivo que descansa em nós, e que no fundo nos guia imaginária, oniricamente. Ao fim, a cultura há de ser sempre controle, regra, interdição, mal-estar. E o mal-estar pode ser a marca da visita a tais imagens. ${ }^{7}$

Passo ao plano político, que nos levará ao visconde de Cairu, e dele a outros autores, para finalmente atingirmos um imaginário bem mais próximo de nós do que podemos supor à primeira vista. 
Mas antes, e fugindo um pouco ao espectro das vitrines do Museu, mas não aos espectros do século XIX, compartilhemos por alguns instantes o incômodo e a fascinação diante de uma outra imagem, a ilustrar o sentido disso a que se pode chamar "encontro" entre a natureza e a humanidade.

Trata-se de um quadro do pintor inglês Richard Ansdell, de 1861, intitulado The Hunted Slaves (Figura 2).

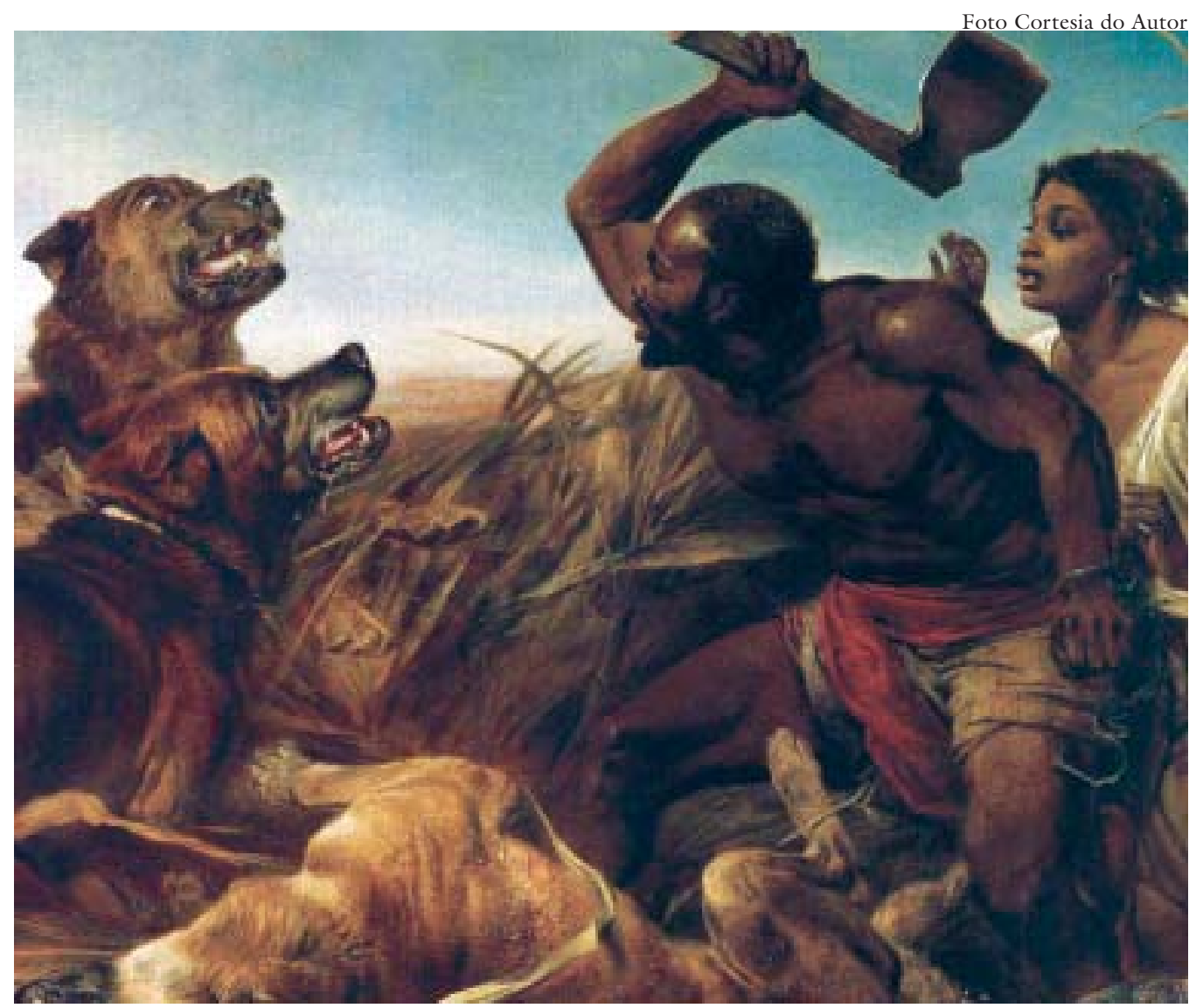

Figura 2 - Richard Ansdell (Liverpool, 1815 - London, 1885). "The Hunted Slaves" [Os escravos perseguidos], 1861. Óleo sobre tela, 184,1 x $308 \mathrm{~cm}$. Board of Trustees of the National Museums and Galleries of Merseyside, Walker Art Gallery, Liverpool.

O que temos aqui? Em primeiro lugar, salta aos olhos o paralelismo sobre o qual se constrói o Encontro. De um lado, dois mastins inequivocamente selvagens, raivosos, descomunais como a Natureza na imaginação do século XIX. De outro, dois escravos fugitivos, nus até onde o decoro vitoriano poderia suportar. No entanto, a proximidade dos pares é inquietante, e perturbadora. Repare-se que o escravo, erguendo o machado, num gesto que seria cunhado pelo cinema clássico contemporâneo como fundacional para a humanidade (refiro-me ao filme de Stanley Kubrick, quando o osso se torna um instrumento), fita os olhos do animal, e o movimento de abertura da sua boca e mesmo o movimento de soerguimento e ameaça vão torná-lo, no fundo, muito semelhante à besta. Ao 
lado, os olhos assustados da escrava miram o outro mastim, que curiosamente porta o olhar talvez mais humano da cena, e que não se sabe ao certo se olha para o escravo que o ameaça ou para a mulher que recua. Em todo caso, a saliva é aqui o resquício corporal da selvageria, ou aquilo que Machado de Assis (1995), jogando com o moralismo bíblico, e colocando-a na boca dos homens, chamaria "a baba de Caim".

O fato é que o paralelismo se faz numa retratação muito complexa, em que sub-repticiamente o espectador pode ser conduzido ao mundo dos iguais, do escravo que, acuado, torna-se selvagem, quase imerso na natureza da qual saiu, talvez não há muito tempo, na imaginação do século XIX. ${ }^{8}$ Esse é um momento significativo, do perigoso (re)encontro da natureza selvagem, e ainda mais impressionante, do ponto de vista político, se nos lembrarmos que as duas figuras humanas ousaram fugir ao âmbito do trabalho, da organização e da norma. Enfim, o que encontram os que ousam subtrair-se à norma, à regulação?

Mas a cena não pára aí, porque o século XIX é sempre muito mais complexo do que se imagina. A tela, pintada no ano em que eclodia a guerra civil americana, marca o momento do encontro, mas afirma, numa espécie de breve paroxismo civilizacional, que o homem já venceu a natureza, e é verdade que o terceiro cachorro (embaixo) é um mastim já vencido, embora a fera eliminada continue perturbadoramente ameaçadora, como a sinalizar ao homem que sua vitória não eliminou completamente o poder selvagem. ${ }^{9}$ O mundo dos instintos, enfim, permaneceria fornecendo o campo para as ciências sociais e médicas, logo mais psiquiátricas.

Dirijamo-nos, entretanto, ao século XIX brasileiro, e à obra riquíssima de Cairu, que anuncia algumas das grandes questões do século XIX, as quais por sua vez retomam, no seu fundo, as discussões sobre a natureza humana que nós sabemos - não se restringem ao século XIX, nem ao XVIII, nem sequer ao XVII.

Dirijo-me a Cairu lembrando uma questão cara ao moralismo do século XVIII, que constitui o tema do capítulo 14 do segundo volume da Constituição moral e deveres do cidadão, intitulado "Da utilidade universal".

Aquilo que se revelava a maior preocupação nas vitrines do Museu de História Natural - a rememoração do momento em que o homem demarca-se frente à natureza, estabelecendo o âmbito social no tecido das normas coletivas - se posta, também em Cairu, no plano moral, no qual as ações são vistas em razão de sua "utilidade universal". Ou seja, o social se afirma contra a natureza, a qual é também um lugar da imaginação, sendo a figuração de um mundo exclusivamente lupino, ou, no caso da iconografia analisada há pouco, exclusivamente canino. Um mundo hobbesiano, embora nunca seja demais lembrar que o pobre Hobbes nunca disse que o homem é apenas o lobo do homem, mas, muito diversamente, sugeriu que o homem pode ser um lobo, como pode ser um deus para o homem. ${ }^{10}$ 
O caminho é bem conhecido: a utilidade universal marca o sentido das ações, que se enfeixam em direção a um télos que é a civilização. Para um leitor tão agudo de Adam Smith como era o visconde de Cairu, não é casual que a moralidade se perfaça exatamente no comércio, e nisso ele não se distancia dos lugares comuns do século. Vejamos o que diz o futuro visconde sobre essa "utilidade universal":

...a utilidade universal é da essência da moralidade e a medida da justiça. Com razão se diz que os princípios da moral são princípios sociais, porque são universais, vista a universalidade de sua operação a bem do gênero humano: eles, por assim dizer, formam o partido da virtude e ordem contra os vícios e desordens, que são os seus inimigos. (Lisboa, 1998, p.199)

Aqui o fio que podemos seguir é semelhante àquele que nos guia pela exposição da "história natural": a busca desejosa do momento em que a sociedade se funda, sendo inevitável que tal fundação se dê no plano moral. Vejamos ainda o que diz Cairu, no mesmo capítulo, apoiando-se em David Hume:

O termo moral envolve a idéia de algum sentimento comum a todo o gênero humano, e que recomenda o seu objeto a geral aprovação, influindo em que quase todos os homens concordem ou discordem na mesma decisão sobre o bem e o mal de tal objeto; ou, em outras expressões, o termo moral envolve algum sentimento tão compreensivo e universal que se estenda às mais remotas nações, como objetos de estima ou censura, conforme se ajustam ou repugnam a alguma estabelecida regra de Direito. (Lisboa, 1998, p.198)

Buscam-se aí os liames capazes de atar o corpo coletivo, e o desmembramento do corpo, na imaginação de Cairu, é a metáfora da própria Revolução. É interessante que a Revolução (um monstro bicéfalo, a atear fogo tanto à França dos jacobinos quanto ao Haiti de Toussaint Louverture) seja figurada, em certo momento da Constituição moral, como uma explosão de átomos, ensejando metáforas orgânicas e médicas de correção e reorganização do corpo (político) mutilado (Monteiro, 2003).

Retomemos a última frase de Cairu: "o termo moral envolve algum sentimento tão compreensivo e universal que se estenda às mais remotas nações, como objetos de estima ou censura, conforme se ajustam ou repugnam a alguma estabelecida regra de Direito". Um leitor consciencioso fará algumas perguntas: que fazem essas "remotas nações" no discurso de Cairu, quais são elas, onde ficam?

Primeiramente, por mais "moderno" que se reclame Cairu, o fato é que as "nações" recobrem aqui quase o mesmo campo semântico que o século XVI já trabalhara, quando se discutia, nas ondas da Segunda Escolástica, o Direito das Gentes. "Nação" é aqui não o termo cunhado com o nacionalismo do século XVIII, e sim, mais propriamente, uma palavra capaz de designar os povos, as nações bárbaras, os "povos ou as gentes da África”, ou seja, os “African peoples” que um turista contemporâneo pode ver no Museu de História Natural de Nova York. 
Ensaiemos, entretanto, um breve passeio duplo. De um lado, aceitemos o convite de Cairu, dando-lhe a mão, mas, de outro, mantenhamos a tela de Richard Ansdell em mente.

"A mais remota nação"... O que exatamente Cairu pretendia quando geografizou essa "nação" no mais remoto ponto em relação ao seu discurso que, como quase todo discurso do século XIX, é o discurso da própria civilização?

Creio que a resposta seja dada por Ansdell (Figura 2): é ao âmbito do trabalho no século XIX, ainda recendendo à colônia, que se reportam ambos. A bem da verdade, será aos africanos que ambos se referem, aos negros que parecem perigosamente fugir desse espaço ausente na pintura (é fundamental que esteja ausente), espaço do trabalho, do mesmo trabalho que desde o Neolítico funda a sociabilidade, porque estabelece a regularidade da ação, o cotidiano da cultura, os espaços proibidos e os permitidos, e organiza o campo dos desejos em torno da interdição. Mas o que nos ensina Ansdell? O que encontra - eu sugeria antes - o fugitivo, quando volta para a floresta, ou seja, quando volta (ou se volta) para a natureza? Justamente o espelho bestial que o século XIX criou para os negros: eu me encontro, refletido nas feras.

Tal história é bastante antiga, e tem raízes muito fundas. ${ }^{11}$

Se ficarmos ainda um pouco com Cairu, logo perceberemos que o seu temor se efetiva precisamente diante dessa espécie de imaginado "retorno" à natureza selvagem, que em tudo se aparta, segundo a velha lição aristotélica, da natureza lógica do homem, afinal um animal político. ${ }^{12}$

No âmbito estrito do debate político, aliás, o deputado constituinte José da Silva Lisboa (que de fato seria agraciado com o título de visconde de Cairu apenas em 1826), na assembléia constituinte de 1823 levantava a voz em favor dos africanos, mas é importante perceber que se trata, no fundo, de um temor, ou do incômodo diante da sua presença, para propor-lhe, finalmente, uma resposta política. Vejamos o que diz nosso moralista:

O temor justo deve ser o de perpetuarmos a irritação dos africanos, e de seus oriundos, manifestando desprezo e ódio, com um sistema de nunca melhorarse a sua condição quando, ao contrário, a proposta liberalidade constitucional deve verossimilmente inspirar-lhes gratidão e emulação, para serem obedientes e industriosos, tendo futuros prospectos de adiantamentos próprios e de seus filhos. (Rodrigues, 1974, p.136)

A resposta à possível irritação funda-se numa liberalidade política habilmente forjada, de modo a inspirar gratidão e emulação, obediência e indústria. Tudo para manter o quadro coeso, como se Cairu pretendesse que os escravos fugitivos retornassem, felizes, a âmbito do trabalho "moderno", ou ainda, que eles nunca precisassem ou desejassem fugir.

É interessante porque o futuro visconde reconhece a diferença desses lugares reservados a brancos e negros, reafirmando-a. Parece que a sua imaginação se desenrola aí, em torno a essa linha divisória. De um lado, a diferença física que 
separa, de outro a lei moral que deve unir. José Honório Rodrigues (1974, p.137) viu em Cairu um homem "relativamente livre dos preconceitos raciais que dominavam o Brasil". No entanto, a passagem em que se apóia é extremamente perturbadora, porque reafirma a diferença, abrindo porventura espaço àquilo que um sociólogo contemporâneo chamou as "ciladas da diferença" (Pierucci, 2000). Ouçamos Cairu:

Deixemos, senhores, controvérsias sobre cores de povos; são fenômenos físicos que variam conforme os graus do equador, influxos do sol e disposições geológicas e outras causas muito profundas, que não são objeto desta discussão... (Apud Rodrigues, 1974, p.137)

Logo em seguida, faz Cairu um elogio dos “crioulos e africanos" que contribuíram para o "estabelecimento do Império", compondo as milícias nacionais.

Mas há uma variação aqui, e essas "causas profundas" são tão mais interessantes quanto indiscutíveis, ou não discutidas.

Guardemos a idéia, e saltemos para um interessante capítulo da Constituição moral, intitulado "Objeções contra o testemunho e poder da consciência", em que Cairu trata de refutar aqueles que punham em dúvida a consciência como voz da Natureza. Com cuidado e detalhe, ele ali trata de ilustrar, em primeiro lugar, aquilo que faz os seus inimigos, no campo da discussão moral, pensarem numa extrema relatividade da Lei, que variaria "conforme aos graus do Equador". Antes, quando a diferença física se apresentava iniludível, Cairu afirmava a variação das cores (ou aquilo que o século XIX logo nomearia "raça", ampliando fantasticamente seu campo imaginativo) conforme os graus do Equador. No entanto, quando se trata da lei moral, apavora-o a simples possibilidade de discutir essa mesma variação, essas mesmas iniludíveis diferenças. É a invariabilidade da lei moral que permite, afinal, delimitar o campo da barbárie, uma "província" que se constitui ao largo da, ou contra a, civilização.

Impressiona, na Constituição moral, o quadro de horrores com que Cairu descreve os povos bárbaros. Destaquemos, dele, uma pequena passagem:

Os selvagens são em toda a parte insentimentais em malfazer, sem a menor compaixão nas torturas com que tiram a vida a seus inimigos, sem horror aos cadáveres que matam e comem. Eles até matam aos pais velhos, não têm pejo das ações mais torpes, não respeitam as próprias mulheres, não se abstêm dos frutos dos trabalhos alheios, estão em contígua guerra de extermínio das tribos circunvizinhas... (Lisboa, 1998, p.221)

E assim segue uma procissão de horrores que não poupa nem os povos modernos, nem os antigos, nem os propriamente "bárbaros". É interessante, entretanto, que o argumento de Cairu contra os "libertinos" que ousaram antepor alguns véus à consciência ${ }^{13}$ seja, finalmente, um argumento aristotélico, que procura retraçar as linhas da sociedade, seguindo, para tanto, o complexo desenho da natureza humana.

Vejamos o que nos traz mais uma passagem do futuro visconde: 
Os monstros físicos não são os padrões da Criação, nem se devem alegar por modelos da Natureza. Bem disse Aristóteles: "O que é natural deve-se considerar nas coisas que operam conforme o seu perfeito estado, e não nas que se acham corruptas". Os selvagens são os monstros da espécie humana, que até deformam a sua fisionomia. Ainda assim, os comuns instintos e sentimentos da humanidade não são neles de todo extintos. Muitas das suas comunidades têm crescido em população; isso prova que tais instintos e sentimentos sempre operam com ação mais ou menos extensa e viva. É fato certo que o estabelecimento dos europeus no Brasil foi originariamente devido à hospitalidade dos selvagens a alguns naufragantes, ainda que praticassem crueldade com outros, seja porque os reputassem inimigos, seja porque sofressem alguma violência. Enfim, o estado selvagem é o mais demonstrativo argumento do pecado original, que reduziu os homens à condição de semibrutos. (Lisboa, 1998, p.223) ) $^{14}$

A passagem é imensamente rica e requer alguma atenção. Em primeiro lugar, o resgate de uma ética aristotélica permite estabelecer, no semblante do homem civilizado (grego, ou, nesse caso, europeu), as linhas da natureza, isto é, da physis. É natural então que a fisionomia - isto é, literalmente as regras, a regularidade da natureza (fisio + nomos) - estampe a correção e a incorreção, a norma e o desvio, o humano e o selvagem. Enfim, a moral se estampa na face humana, e eu sou capaz de estabelecer, desde o ponto de vista civilizado, as linhas que me separam do selvagem, a que o próprio homem, meu semelhante, pode regressar, como se tomasse por um momento o caminho desviante que o leva de volta à natureza, de volta à selva.

Mas há algo mais nessa figuração de Cairu. Em bom raciocínio teológico, Silva Lisboa não imagina o selvagem como a figura intocada com que certa vertente do Romantismo figuraria o índio, mais que o negro. De qualquer maneira, o que informaria a idealização do selvagem no século XIX brasileiro ainda são, para a imaginação romântica, as teorias de Rousseau e a sua vulgarização, que Cairu refuta vigorosamente.

O selvagem tampouco seria, no seu raciocínio, o papel em branco com que o figurara o padre Manuel da Nóbrega, imaginando-o, num primeiro momento, pronto a receber a mensagem cristã (Holanda, 1992, p.308-9). Cairu é de certa forma menos benevolente, porque nos põe a todos na linhagem adâmica e, portanto, todos caminhamos num mundo já manchado pelo pecado original. ${ }^{15}$ Mas é aí - justamente aí! - que os negros carregam uma dupla mácula, sua dupla falta. Por um lado, o pecado original que nos faz a todos imperfeitos, incapazes de atravessar novamente os jardins edênicos. Por outro, parece que os selvagens lugar que a imaginação científica do século XIX reservaria também aos negros têm uma segunda marca de imperfeição, que é o seu insucesso na marcha da civilização, porque para Cairu e para o seu século os homens selvagens não se encontram nem na selva nem na cidade, nem do lado das feras nem dos homens. Os homens selvagens se encontram no caminho, no Encontro, nem brutos, nem civilizados. Semibrutos, ou homens brutos. 
Abandonemos agora a imagem sugerida por Ansdell, para voltar ainda um pouco no tempo, e mirar por um breve instante uma das inquietantes fontes desse temor que todos sentimos da regressão - um temor que se sabe, que Sade, que todos sabemos, mistura-se ao desejo e à pulsão, quando se trata do retorno definitivo ao animal, ao corpóreo, ao bestial, àquilo que nos faz iguais, rigorosamente os mesmos que os animais.

Refiro-me à forma como essas seculares discussões sobre a natureza humana atingiram o século XVII. Naquele tempo, o pintor Charles Le Brun desenhava estes que são os mais perturbadores dos retratos humanos, marcando um velho campo que os franceses logo nomeariam physiognomonie, retomando nisso uma tradição antiga que atravessa a Idade Média e se atualiza no Renascimento, e que se traduz pelo português "fisiognomonia", que o Houaiss define como a "arte de conhecer o caráter do indivíduo a partir de suas feições".

Vejamos, na Figura 3, alguns casos.
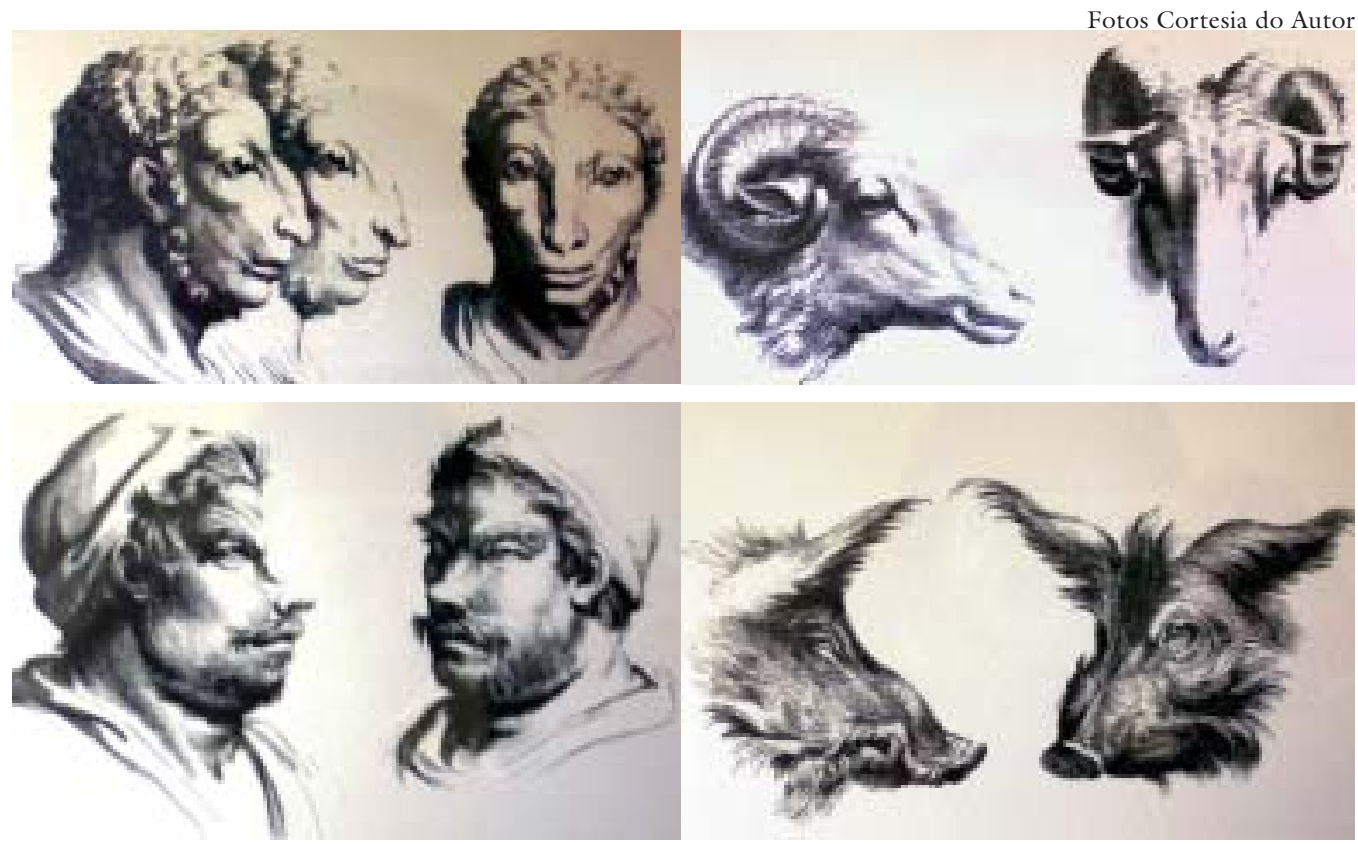

Figura 3 - Charles Le Brun. Retratos fisiognomônicos. Paris, Louvre, Gabinete dos Desenhos.

Talvez o que mais chame a atenção, claro, não seja a verossimilhança, mas essa projeção em que o humano se desfigura, ou antes, se reconfigura no animal. Por certo, há um lugar comum infernal, em que os homens têm rabos, chifres, tantos pêlos quanto os macacos, e essa é a linhagem antiga dos bestiários, que nos levaria também muito longe. ${ }^{16}$ Mas o que faz os retratos de Le Brun tão inquietantes será porventura a proximidade, as tomadas sucessivas dos dois momentos, o humano e o seu espelho animal. O humano e o caráter animal que the corresponde. 
Não me estendo no tema (o que seria motivo de mais um ensaio), mesmo porque outros já o fizeram. ${ }^{17}$ Penso apenas, seguindo sugestões anteriores, no quanto esse tipo de retrato pode ajudar a compreender a literatura dita "realista", nos retratos um pouco bestiais dos homens do povo, na pena de Zola, ou, no quadrante literário brasileiro, nos personagens d'O cortiço, de Aluísio Azevedo (cf. Fontes, 1998).

Há algo como uma linha, um movimento de longa duração, ao longo da qual a investigação do humano, na sua proximidade com o animal, se presentifica. Tal investigação se encontra na fisiognomonia de Lavater, estava presente nos retratos de Le Brun, como já estivera nas gravuras de Della Porta, estaria na frenologia de Gall, estará porventura na moderna criminologia de Lombroso, para, finalmente, despontar, como flor mórbida, nas teorias dos cientistas do III Reich. $\mathrm{O}$ indesejado vai se tornando cada vez mais parecido aos animais: os negros aos macacos, os judeus aos ratos, as mãos destes às garras das aves de rapina, e assim por diante. ${ }^{18}$

Mas talvez não seja necessário ir tão longe, ou tão perto.

Se nós nos limitássemos a referências todavia mais nobres, ou literariamente mais ricas, ou ainda politicamente mais complexas e inclusive menos tortas, poderíamos mergulhar na prosa civilizada que o século XIX criou e que no século XX floresceu nessa obra-prima da literatura brasileira: Os sertões, de Euclides da Cunha.

O "clã tumultuário de Antônio Conselheiro", "o povoado em leito escavado e fundo, como um fosso":

Canudos, assim circunvalado quase todo pelo Vaza-Barris, embatia ao sul contra as vertentes da Favela e dominado no ocidente pelas lombas mais altas de flancos em escarpa em que se comprimia aquele nas enchentes, desatava-se para o levante segundo o expandir dos plainos ondulados. As montanhas longínquas fechavam-se em roda, formando, quase contínua, uma elipse de eixos dilatados. Feitos postigos em baluarte desmedido, abriam-se, estreitas, as gargantas em que passavam os caminhos... (Cunha, 2001, p.295)

Eis que vemos, na prosa maior de Euclides, um povoado que mal aflora da terra, que a natureza parece querer consumir, tomar de volta para si, engolindo-o com suas gargantas rochosas. Tudo, em Os sertões, é proximidade com a natureza; o drama mesmo se dá no encontro da civilização, no espelho que a República criara, na imagem selvática em que o civilizado não pode, não deve, ou não quer se reconhecer.

Mas é interessante que o sertão seja um paraíso... É interessante que tudo ali conspire contra a civilização, respire com a natureza, como num mundo à margem da história. Mas o homem, o que é o homem?

"Hércules-quasímodo", criatura de fronteira, aqui feio e fraco, logo pujante e admirável, num eterno "equilíbrio instável”. É da instabilidade que nos fala Euclides da Cunha. É a instabilidade da raça que o atormenta, mas é fantásti- 
ca a inversão que ele promove e que impressiona a nós, leitores contemporâneos: não são os homens do litoral a raça forte, mas a gente insulada no sertão, essa sim guarda a força telúrica que falta à República, a qual é um engano, uma farsa, um mal-entendido, uma máquina tresloucada que perpetra o Crime.

Não se pode esquecer do retrato célebre do Conselheiro, "documento raro de atavismo", um desses "patrícios retardatários", "anticlinal extraordinária" da "nossa estratificação étnica":

Evitada a instrusão dispensável de um médico, um antropologista encontrálo-ia normal, marcando logicamente certo nível da mentalidade humana, recuando no tempo, fixando uma fase remota da evolução. O que o primeiro caracterizaria como caso franco de delírio sistematizado, na fase persecutória ou de grandezas, o segundo indicaria como fenômeno de incompatibilidade com as exigências superiores da civilização, - um anacronismo palmar, a revivescência de atributos psíquicos remotíssimos... (Cunha, 2001, p.254)

Remotíssimos... No superlativo euclidiano, fundamental numa prosa de paroxismos, podemos sondar aquilo que a mesma palavra buscava significar, na prosa muito mais pobre e desgraciosa do visconde de Cairu. Lá, na Constituiçãa moral, a idéia de que as nações mais remotas pudessem subtrair-se ao âmbito do Direito estorvava o visconde, e ele reclamava "algum sentimento tão compreensivo e universal que se estenda" até elas (“às mais remotas nações”). Já aqui, em Euclides da Cunha, o universo todo de sua reportagem é remoto, e faz parte de sua arte retórica e lógica que o remoto seja deslocado para o seu extremo e limite: remotíssimo...

Por fim, exemplo máximo da remoção (que é o deslocamento, o afastamento) se encontra nas linhas finais de Os sertões, página maior que eu não ousaria citar senão inteira.

Canudos não se rendera, e o arraial caiu em 5 de outubro de 1897. No dia seguinte, antes que os soldados destruíssem as 5.200 casas dos sertanejos, uma comissão descobre o cadáver de Antônio Conselheiro:

Jazia num dos casebres anexos à latada, e foi encontrado graças à indicação de um prisioneiro. Removida breve camada de terra, apareceu no triste sudário de um lençol imundo, em que mãos piedosas haviam desparzido algumas flores murchas, e repousando sobre uma esteira velha, de tábua, o corpo do "famigerado e bárbaro" agitador. Estava hediondo. Envolto no velho hábito azul de brim americano, mãos cruzadas ao peito, rosto tumefato, e esquálido, olhos fundos cheios de terra - mal o reconheceram os que mais de perto o haviam tratado durante a vida.

Desenterraram-no cuidadosamente. Dádiva preciosa - único prêmio, únicos despojos opimos de tal guerra! -, faziam-se mister os máximos resguardos para que se não desarticulasse ou deformasse, reduzindo-se a uma massa angulhenta de tecidos decompostos.

Fotografaram-no depois. E lavrou-se uma ata rigorosa firmando a sua identidade: importava que o país se convencesse bem de que estava, afinal, extinto aquele terribilíssimo antagonista. 
Restituíram-no à cova. Pensaram, porém, depois, em guardar a sua cabeça tantas vezes maldita - e, como fora malbaratar o tempo exumando-o de novo, uma faca jeitosamente brandida, naquela mesma atitude, cortou-lha; e a face horrenda, empastada de escaras e de sânie, apareceu ainda uma vez ante aqueles triunfadores...

Trouxeram depois para o litoral, onde deliravam multidões em festa, aquele crânio. Que a ciência dissesse a última palavra. Ali estavam, no relevo de circunvoluções expressivas, as linhas essenciais do crime e da loucura... $(\mathrm{Cu}-$ nha, 2001, p.779-80)

A remoção do cadáver, a remoção da cabeça, as remotas nações, os remotíssimos atributos psíquicos.

Os indesejados são projetados sobre o passado - da história natural dos povos -, e se procura, com a imagem, ou a imaginação, fixá-los num outro tempo, como se a fixação alhures pudesse realmente afastá-los de nós, numa espécie de exorcismo civilizador. É bem esse o sentido da foto célebre do que restou do tempo remoto de Canudos.

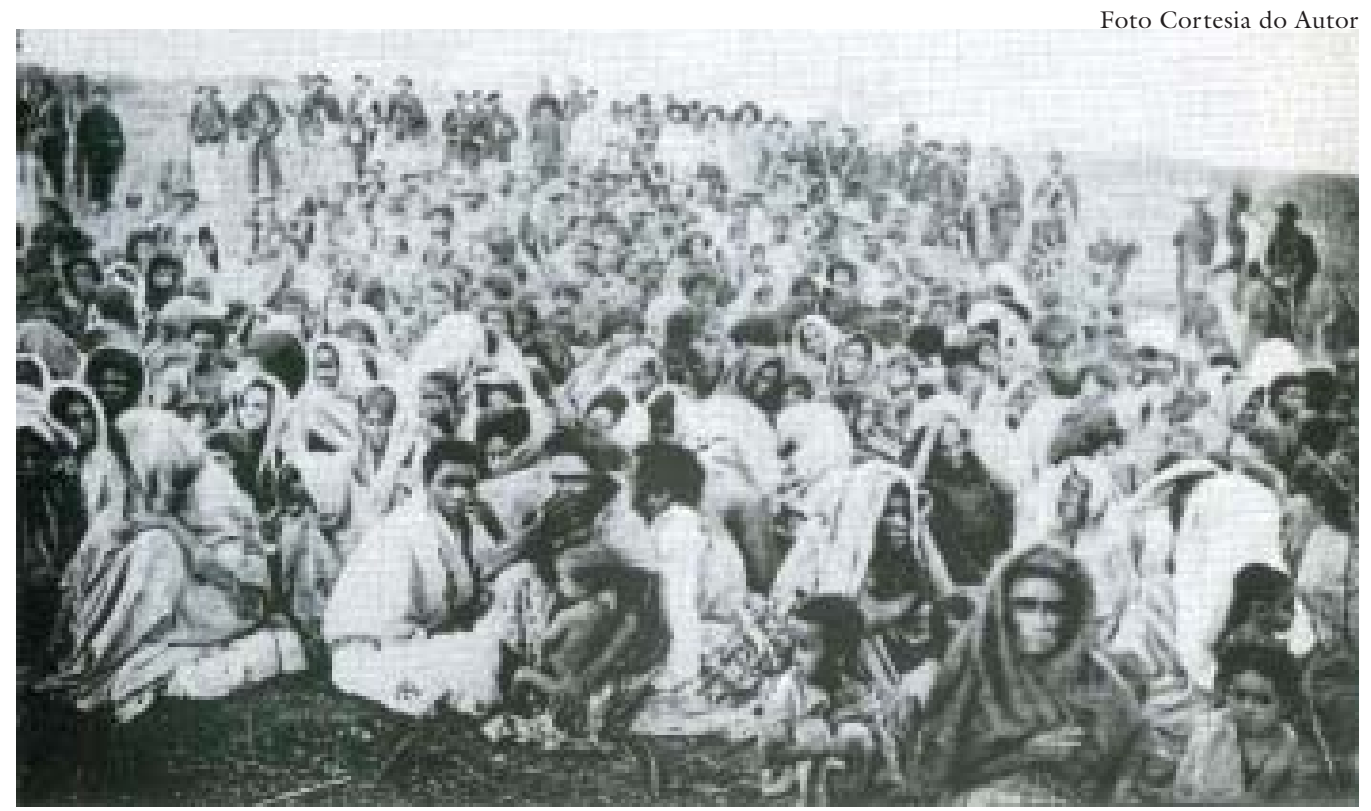

Figura 4 - As prisioneiras. Foto de Flávio de Barros.

É um mundo regressivo, retroativo, necessariamente pregresso. Universo espectral - justamente o espectro do homem, num espelho diabólico que o século XIX criou e que retraça o caminho imaginário que nos separa "deles", porque se quer mantê-los longe, fixá-los num outro lugar. Removê-los. ${ }^{19}$

Por fim, não se diga que a foto ou as imagens todas são tão antigas. Não vale a pena acreditar completamente nessa remoção. Basta que se pense na revivescência do tema euclidiano, quando a fala civilizada desperta os fantasmas do primitivo. Basta que se recorde: há não muitos anos, os preconceitos sulistas 
contra os nordestinos pareciam acendrar-se numa projeção fantasmagórica. Quem não se lembra do "homem-gabiru"? Pequeno, feio, desengonçado, pele escura, ele surgia nas fotos da imprensa sulina, "civilizada", numa ambiência claramente neolítica: afastado no tempo, apoiado quando muito sobre um instrumento agrícola rudimentar, numa proximidade inquietante com a natureza...

Enfim - a tanto resume-se minha sugestão -, vale a pena investigar até onde a construção de um discurso civilizado é, ainda e por muito tempo, uma empresa exorcística. E o interessante, no campo das ciências humanas e da literatura, será perceber que esse afastamento do indesejado esconde o desejo, e com ele o temor do encontro.

Mas encontro de quê?

Do homem, talvez.

Notas

I A Constituição moral mereceu, entretanto, uma cuidadosa edição contemporânea de seus três primeiros volumes, com comentários esclarecedores a cargo de Anoar Aiex (cf. Lisboa, 1998). Sobre Cairu, recomendo em especial três trabalhos recentes: Rocha (1996); Lustosa (1999); Novais \& Arruda (1999).

2 Procurei, diante da Constituição moral e deveres do cidadão, ouvir um diálogo, algumas vezes claro, outras cifrado, com o moralismo francês do século XVII. O fantasma que então me acompanhou, e que eu havia reconhecido na obra de Cairu, foi o duque de La Rochefoucauld, o famoso autor das máximas em que a virtude humana é relativizada, ridicularizada e, no limite, contestada. Na sua obra moral, Cairu traduziu e explicou (ou exemplificou, na melhor tradição retórica) as máximas francesas, oferecendo ao jovem leitor brasileiro o quadro do homem perdido, flagrado em sua decadência e na selvageria de sua natureza corrompida. Entretanto, ainda dentro de claros princípios retóricos e pedagógicos (que podem ser o mesmo), esse retrato era oferecido à "Mocidade" brasileira como um negativo: ali no desenho do homem regido pelo amorpróprio e pela vaidade, Cairu via o contrário - o exato contrário - do que seria a postura virtuosa que ele julgava necessário despertar na juventude do Império nascente. Ou seja, ao incluir as máximas de La Rochefoucauld na sua Constituição moral e deveres do cidadã 0 , Cairu revelava o que a juventude brasileira nãa deveria seguir, ou aquilo exatamente que lhe serviria como uma ética especular - não esquecendo que os espelhos invertem aquilo que se imagina, que se torna imagem. O resultado principal dessa pesquisa encontra-se em Monteiro (2004).

3 Interessante será também pensar na laicização e catalogação do espaço colonial, ou pós-colonial, quando os museus podem surgir para resguardar (ou retraçar) os momentos fundacionais de antigas civilizações, tornando-as, entretanto, objeto de admiração ou consumo, esvaziadas de todo caráter sagrado original - o que possibilita porventura a máxima reapropriação desse mesmo espaço que a metrópole ia perdendo, agora recolonizado pelo olhar científico e finalmente habitado pela curiosidade turística. Sobre o tema, ver Anderson (2003, p.178-85).

4 Um museu é o século XIX. Por certo a assimilação de um olhar classificatório (e hierarquizante) na perspectiva de uma institucionalização da curiosidade (e narrativa) 
histórica requereria uma bem fundada investigação sobre a história não apenas do museu no século XIX (e dos museus, ou do Museu de História Natural de Nova York em particular), mas das próprias disciplinas que fundam o campo científico contemporâneo. Só uma pesquisa desse tipo permitiria porventura atenuar o caráter categórico da asserção que torna o museu a um só tempo uma criatura e a projeção daquele século. Não seria demasiado lembrar, aliás, que o museu se configura não apenas como uma narrativa linear (da história dos povos, do homem, das nações), mas, para utilizar a iluminadora imagem de Clifford, buscada a Mary Louise Pratt, como uma "zona de contato" entre culturas, perspectivas e agentes - conquanto o peso do olhar científico não permita esquecer o eixo eurocêntrico em torno ao qual giram os interesses museológicos. De Clifford, ver "Museums as Contact Zones" (1997). Talvez a assertiva ficasse melhor se sugerido que o museu não é uma simples expressão do século XIX, mas, mais propriamente, é uma das modalidades possíveis de um discurso civilizado que se afirma e canoniza naquele século, sem que isso signifique que a legitimação dos valores então em pauta (ou em cena) se dê sem conflitos. Em outros termos, é difícil (e talvez nem seja desejável) imaginar que as criaturas "congeladas" nas vitrines do Museu de História Natural sejam apenas objetos. Afinal, a projeção dos temores civilizados não encontra, mesmo naquele espaço, um vazio onde possa pacificamente concretizar uma imagem previamente sonhada. A projeção é também uma reação e, nesse aspecto, as figuras retratadas são mudas, mas não deixam de provocar e produzir sentidos cuja complexidade não provém apenas do espaço civilizado, mas, plausivelmente, provém desse estranho espaço que se nomeia "selvagem" - ele mesmo uma fantástica "zona de contato".

5 No original: "Among the Pokot, as with many grassland peoples, cultivation is as economically important as herding, but herding is closely associated with notions of wealth and prestige, and linked to religious values. A focal point of each day is the painless drawing of a small quantity of blood from the necks or young oxen, which do not suffer, as no one ox is bled more than once every month or two. Just as the fields are the province of women, so is the cattle compound the province of men. Men divide themselves into various age grades, each with an appropriate role to play, and each distinguished by manners of speech and dress. On occasions such as this one, several grades may cooperate, on others they must be separated. Women may be seen coming down from the irrigated fields of the highland masob, while cattle are driven up from the lowland keiou. The central kamass is also the social center where all Pokot interact, and contains the ritual shrines where all must gather" " "The Rift Valley in northwest Kenya, north of Sigor, looking west to the escarpment that rises 2,000 feet to the Kanimojong plains of Uganda". American Museum of Natural History, Hall of African Peoples, 2003).

6 Ver, sobre a gênese de um pensamento sociológico clássico em Durkheim, Fernandes (1996).

7 Nunca é demais repisar a idéia de que Freud escreveu, como tantos outros em seu tempo, sob o impacto daquelas revelações da antropologia do final da era vitoriana. Assim, parece provável, se não evidente, que também ele tivesse diante de si esse novo museu do homem, para ali buscar, entre fascinado e perturbado, uma espécie de fundação do humano, localizando-a, na cronologia fantástica do novo campo, no momento da morte de um Pai primevo - instante que se repetiria, como uma constante macabra, no pulso do desejo que o pai da psicanálise persegue. A passagem é conhecidíssima: "certo dia, os irmãos que tinham sido expulsos retornaram juntos, 
mataram e devoraram o pai, colocando assim um fim à horda patriarcal. Unidos, tiveram a coragem de fazê-lo e foram bem-sucedidos no que lhes teria sido impossível fazer individualmente. (Algum avanço cultural, talvez o domínio de uma nova arma, proporcionou-lhes um senso de força superior.) Selvagens canibais como eram, não é preciso dizer que não apenas matavam, mas também devoravam a vítima. $\mathrm{O}$ violento pai primevo fora sem dúvida o temido e invejado modelo de cada um do grupo de irmãos: e, pelo ato de devorá-lo, realizavam a identificação com ele, cada um deles adquirindo uma parte de sua força" (Freud, 1974, p.170).

8 Embora não só na imaginação daquele século. É preciso lembrar, para além do evolucionismo (sobre cuja lógica se estabeleceriam as hierarquias raciais que herdamos do século retrasado), a brutal consciência do tempo na história humana - algo que a fantasia do encontro do homem em sua infância histórica trataria de despertar, não apenas com a América fantástica de Humboldt, mas já desde os primeiros encontros americanos, a partir do annus mirabilis de 1492 . Conquanto a fantasia européia retomasse passos antigos rumo à origem imaginária da humanidade, será porventura verdade que o encontro do Novo Mundo marca o tempo da rediscussão da natureza humana, coalhando as paragens americanas de figuras conhecidas dos europeus, mas ao mesmo tempo assinalando a necessidade de uma espécie de mergulho no mundo natural (a exegese do Livro da Natureza, a marcar progressivamente os cânones da nova ciência), como se os homens mirassem sua própria origem, depositando sua desconfiança ou sua fé naquilo que viam, ou pensavam ver. Sobre tais "encontros", ver Pagden (1993).

9 Que o mastim seja um cão adestrado não é fato que invalide a tese desse terror selvagem inspirado por suas enormes mandíbulas e por sua saliva. Mas certamente repõe uma questão importante, que é o controle da natureza selvagem, em prol da manutenção dos limites precários da cidade - ou aqui, dos limites precários do âmbito do trabalho. De resto, a utilização do machado como arma é já uma inversão da funcionalidade sobre a qual se funda o espaço do trabalho, e sobre a qual se desenha essa geografia também ela fantástica, que associa os homens às suas funções, mas que oculta, não raro, o caráter social de sua submissão à materialidade do mundo.

10 "Hobbes tem fama tão ruim que desta imagem [o homem para o homem é um lobo] sempre se repete a primeira parte e se omite a segunda [o homem para o homem é uma espécie de Deus]" (Ribeiro, 1984, p.48).

11 A idéia de um espelhamento, resgatando com detalhe os motivos mais antigos de uma regressão à selva (ou os motivos amiúde pagãos do "homem silvestre"), encontra-se fantasticamente desenvolvida em Bartra (1992).

12 Sem esquecer, entretanto, a dimensão (já aristotélica) do domínio que a Cidade exerce sobre o cidadão, ou, nos termos de Agamben (que, por seu turno, estendem as investigações de Foucault sobre o campo da biopolítica), a soberania sobre a "vida nua" expressão que o filósofo italiano vai buscar às reflexões de Benjamin sobre a violência (cf. Agamben, 1998).

13 Ora, não à toa os "casuístas" arbitrários e cerebrinos são os autores do verbete "Consciência" da Enciclopédia, que "dão tantas regras sobre a consciência verdadeira e duvidosa, que tiram todo o crédito à mesma consciência" (Lisboa, 1998, p.222-3).

14 Sigo os destaques dados pelo editor, salvo no caso de "semibrutos", vocábulo que se encontra em itálico no original de 1825 , mas não na edição paraibana. 
15 Que se pense na caraterização fundamental de Carl Schmitt, para quem a definição do Romantismo podia dar-se em torno dessa subtração à órbita do pecado original. Claro, o que o apavorava era o "ocasionalismo", os desenhos políticos incontroláveis, que potencialmente se subtraem à ordem da coletividade (cf. Schmitt, 2001).

16 Mais uma vez, a metáfora do espelho pode ser interessante. E vale ressaltar, nesse jogo imagético, a necessária proximidade do selvagem, que surge nas raias da cidade, podendo coabitar o espaço humano - ao menos, ou justamente, em seus limites. Ver, aqui também, Bartra (1992).

17 Ver, a propósito, Dantas (1992). Ou ainda, Baltrusaitis (1995/1996).

18 Apavorante é que as conseqüências políticas dessa afirmação dos traços selvagens na face do indesejado estejam presentes numa certa retórica nossa conhecida, sobre a qual se monta muito discurso policial da imprensa contemporânea, muita falação nos programas de rádio, e que pode ser flagrada na tribuna política cada vez que um Afanázio Jazadi ou um Ratinho é eleito, pelo mesmo povo, aliás, sobre o qual eles atiram o selo do "selvagem", ou sobre o qual deixam pairando a suspeita de selvageria. E assim, cada vez que eu, parte desse "povo", escapo ao círculo da selvageria e posso me reconhecer fora da moldura do selvagem, convém quebrar o espelho, antes que me mostrem que eu mesmo sou o monstro. Ou, nos termos desses estuporados, convém eliminar o selvagem, num processo de purgação social ritual e violento, a que a jurisprudência moderna chama "pena de morte". Ainda sobre essa figura animalesca do homem banido, vale lembrar, com Agamben (1998, p.105), a história do mitologema hobbesiano: "O que tinha de restar no inconsciente coletivo como um híbrido monstruoso de homem e animal, dividido entre a floresta e a cidade - o lobisomem - é na sua origem, portanto, a figura do homem que foi banido da cidade. Que tal homem seja definido como um homem-lobo e não simplesmente como um lobo (a expressão caput lupinum tem a forma de um estatuto jurídico) é decisivo aqui. A vida do banido, como aquela do homem sagrado, não é uma peça de natureza animal sem qualquer relação com a lei e a cidade. Ela é, bem mais, o espaço de indistinção e de passagem entre o animal e o homem, physis e nomos, exclusão e inclusão: a vida do banido é a vida do 'loup garou, o lobisomem, que não é precisamente nem homem nem besta, e que pertence paradoxalmente aos dois sem pertencer a nenhum".

19 É verdade, porém, que o procedimento não é novo: haverá aí um velho lugar da imaginação civilizada, como pode sugerir o canto homérico, quando, lamentando que Netuno obstasse a Ulisses o retorno a Ítaca, lembra, logo nos primeiros versos, que aquele "era entre os Etíopes longínquos,/ Do Oriente e Ocidente últimos homens, / Num de touros e ovelhas sacrifício,/ A deleitar-se..." (Odis. 1, 22-25) - aqui, na controversa tradução de Odorico Mendes (cf. Homero, 2000, p.66). Imagine-se, entretanto, o alcance semântico daqueles "eschatoi andrôn", a indicar o extremo que habitavam os homens de pele adusta (aliás, Cairu pertence ainda a um tempo em que genericamente podiam chamar-se aos negros africanos "etíopes" - literalmente, os de "pele queimada"), divisos e porventura dividindo o mundo entre o que é e o que não é humano - "the world's extremest verge", na notação de Pope. Para a tradução deste último, vali-me dos arquivos do Projeto Gutenberg (http://promo.net/pg/); para o texto grego e comentários, das páginas da Biblioteca Digital Perseus (http:// www.perseus.tufts.edu/). 
Referências bibliográficas

AGAMBEN, G. Homo Sacer: sovereign power and bare life. Transl. Daniel Heller-Roazen. Stanford: Stanford University Press, 1998.

ANDERSON, B. Imagined Communities: reflections on the origin and spread of nationalism. London; New York: Verso, 2003. p.178-85.

BALTRUSAITIS, J. Aberrações - Ensaio sobre a lenda das formas. "Fisiognomonia Animal". Trad. Luiz Dantas. Revista de História da Arte e Arqueologia, Campinas, n.2, p.331-53, 1995/1996.

BARTRA, R. El Salvage en el espejo. México, DF: Universidad Nacional Autónoma de México/ Ediciones Era, 1992.

CLIFFORD, J. Museums as Contact Zones. In: Routes: Travel and Translation in the Late Twentieth Century. Cambridge MA; London: Harvard University Press, 1997.

CUNHA, E. da. Os sertões (Campanha de Canudos). Ed. Leopoldo M. Bernucci. São Paulo: Ateliê Editorial, Imprensa Oficial do Estado, Arquivo do Estado, 2001.

DANTAS, L. Francis de Castelnau e o relato de um grupo de escravos de Salvador da Bahia em 1851. Ou do caráter simiesco dos indesejáveis. Remate de Males, Campinas, n.12, p.45-55, 1992.

FERNANDES, H. R. Um século à espera de regras. Tempo Social, São Paulo, v.8, n.l, p.71-83, maio 1996.

FONTES, J. B. A corrupção da natureza. Revista Entretextos Entresexos, GEISH/Unicamp, n.2, p.9-53, out. 1998.

FREUD, S. Totem e tabu. In: Edição standard das Obras psicológicas. Trad. Orizon Carneiro Muniz. Rio de Janeiro: Imago, 1974. v.XIII (1913-1914), p.170.

HOLANDA, S. B. de. Visão do paraiso. São Paulo: Brasiliense, 1992.

HOMERO. Odisséia. Trad. Manuel Odorico Mendes. Ed. Antonio Medina Rodrigues. São Paulo: Edusp, 2000.

LISBOA, J. da S. [Visconde de Cairu] Constituição moral e deveres do cidadão com exposição da moral pública conforme o espírito da Constituição do Império. Ed. Anoar Aiex. João Pessoa: Editora Universitária/UFPB, 1998.

LUSTOSA, I. Cairu, panfletário: contra a facção gálica e em defesa do Trono e do Altar. Rio de Janeiro: Fundação Casa de Rui Barbosa, 1999. ("Papéis Avulsos", n.34)

MACHADO DE ASSIS, J. M. Memórias póstumas de Brás Cubas. Rio de Janeiro, Garnier, 1995. (cap.6).

MONTEIRO, P. M. Cairu e a patologia da Revolução. Estudos Avançados, São Paulo, v.17, n.49, p.349-58, 2003.

MONTEIRO, P. M. Um moralista nos trópicos: o visconde de Cairu e o duque de La Rochefoucauld. São Paulo: Boitempo, 2004.

NOVAIS, F. A.; ARRUDA, J. J. de A. Prometeus e Atlantes na Forja da Nação. In: LISBOA, J. da S. Observações sobre a franqueza da indústria, e estabelecimento de fábricas no Brasil. Brasília: Senado Federal, 1999.

PAGDEN, A. European Encounters with the New World: from Renaissance to Romanticism. New Haven; London: Yale University Press, 1993. 
PIERUCCI, A. F. Ciladas da diferença. São Paulo: Editora 34, 2000.

RIBEIRO, R. J. Ao leitor sem medo: Hobbes escrevendo contra o seu tempo. São Paulo: Brasiliense, 1984.

ROCHA, A. P. A economia politica na sociedade escravista (um estudo dos textos econômicos de Cairu). São Paulo: Departamento de História-usp/Hucitec, 1996.

RODRIGUES, J. H. A Assembléia Constituinte de 1823. Petrópolis: Vozes, 1974.

SCHMITT, C. Political Romanticism. Transl. Guy Oakes. Cambridge; London: The MIT Press, 2001.

Resumo - PARTindo da obra de José da Silva Lisboa, o visconde de Cairu, o artigo trata do lugar imaginário em que se situa o Outro da civilização. Pretende-se, por intermédio dele, inquirir e explorar a distância que separa o civilizado do bárbaro. No espaço intermédio entre a barbárie e a civilização, afinal, a literatura social desenha o território fronteiriço em que o discurso civilizado reaviva os fantasmas da regressão, trabalhando poeticamente o horror do retorno à selva. Trata-se de uma longa tradição literária que, no Brasil, tem em Euclides da Cunha o seu mestre.

PALAVRAS-CHAVE: Literatura e moral, Civilização e barbárie, José da Silva Lisboa (17561835), Euclides da Cunha (1866-1909).

ABSTRACT - BASED ON the work of José da Silva Lisboa, the Viscount of Cairu, this article discusses the imaginary place of the Other in civilization. The objective of the article is to inquire into and explore the distance that separates civilized people from barbarians. In the intermediate space between civilization and barbarity, social literature plots out the frontier where civilized discourse revives fantasies of regression and poetically evokes the horror of a return to the jungle. This is a long literary tradition which, in Brazil, has Euclides da Cunha as its master.

KErWORDS: Literature and moral, Civilization and barbarity, José da Silva Lisboa (17561835), Euclides da Cunha (1866-1909).

Pedro Meira Monteiro é professor-assistente de Literatura Brasileira na Universidade de Princeton, Estados Unidos. É autor, entre outros, de Um moralista nos trópicos: o visconde de Cairu e o duque de La Rochefoucauld (Boitempo, 2004). A redação deste ensaio iniciou-se com a participação no simpósio "Moralidade e Política", na Universidade Federal do Piauí, em Teresina, em junho de 2003. O autor agradece aos colegas da UFPI, expositores e comentadores, a interlocução privilegiada; e muito especialmente a João Kennedy Eugênio a acolhida generosa e o diálogo constante. Em Princeton, o ensaio contou com a leitura provocativa de Paul Firbas e de Arcadio Díaz-Quiñones. @ - pmeira@Princeton.edu

Recebido em 10.10.2005 e aceito em 20.12.2005. 